\title{
LA POTESTAD REVOCATORIA DE LOS ACTOS ADMINISTRATIVOS*
}

\section{JuAN CARlos Flores Rivas ${ }^{* *}$}

RESUMEN: El artículo 61 de la Ley No 19.880 de 2003, que establece las Bases de los Procedimientos Administrativos que rigen los Actos de la Administración del Estado, regula la potestad que le permite a los órganos de la Administración del Estado volver a revisar los actos administrativos válidos, ya sea por razones de oportunidad, mérito o conveniencia. No obstante, este artículo no profundiza en el concepto, los requisitos y límites para ejercicio de la potestad revocatoria, ni tampoco en la relación que existe entre esta potestad y las demás potestades para extinguir los actos administrativos. En este trabajo se analiza la regulación de la potestad revocatoria contemplada en el artículo 610 de la Ley No 19.880 de 2003; su objeto, requisitos, fundamentos y las limitaciones aplicables a su ejercicio desde una perspectiva dogmática y jurisprudencial. Se intentará comprobar si la revocación de los actos administrativos constituye la regla general en nuestro ordenamiento jurídico, o si dicha potestad debe ser interpretada en términos estrictos.

PALABRAS CLAVE: Potestad revocatoria - acto administrativo - procedimiento - límites.

\section{THE REVOCATION OF ADMINISTRATIVE AUTHORITY}

ABSTRACT: The article 61 of Law $N^{\circ} 19,880$ from 2003, which establishes the basis of the Administrative Procedures governing the Acts of the State Administration, regulates the power that allows the organs of State Administration revisiting valid administrative acts, for no other reasons than opportunity, merit or convenience. However, this article does

Fecha de recepción: 28 de diciembre de 2015.

Fecha de aceptación: 26 de mayo de 2016.

** Doctor en Derecho. Profesor de Derecho Administrativo, Universidad de los Andes, Santiago, Chile. Dirección Postal: Mons. Álvaro del Portillo 12.455, Las Condes, Santiago. jcflores@miuandes.cl 
not delve into the concept, requirements and limits for the exercise of power nor recall the relationship between this authority and other powers to extinguish administrative acts. The regulation of the revocation authority referred to in Article 61 of Law No. 19,880 from 2003, is analyzed along this paper, together with its purpose, requirements, rationale and limitations applicable to the exercise from a dogmatic and jurisprudential perspective. Finally, many attempts are made to prove if the revocation of administrative acts is the general rule in our legal system, or whether this power should be interpreted strictly speaking.

KEY WORDS: Revocation authority - administrative act - procedure - limits.

Sumario: Introducción; 1) Potestades de retiro de los actos administrativos; 2) Potestad invalidatoria y revocatoria. Semejanzas y diferencias; 3) Análisis especifico del artículo 61 de la Ley $N^{\circ}$ 19.880, de 2003; (3.1.) Concepto de revocación en la Ley $N^{\circ} 19.880$, de 2003; (3.2.) Sujeto activo de la revocación administrativa; (3.3.) Objeto de la revocación administrativa; (3.4.) Motivo de la potestad revocatoria; (3.5.) Fundamento normativo de la revocación administrativa; (3.6.) Efectos de la revocación administrativa; 4) Limitaciones a la potestad revocatoria; (4.1.) Actos declarativos o creadores de derechos adquiridos legitimamente; (4.2.) La situación especial de los actos administrativos de gravamen; (4.3.) Improcedencia de la revocación de actos administrativos reglados; Conclusiones; Bibliografia; Jurisprudencia.

\section{INTRODUCCIÓN}

En el desarrollo de la teoría del acto administrativo, detenta una posición significativa el estudio de las potestades de retiro que ostenta la Administración del Estado para revisar el contenido o los efectos de los actos administrativos en un determinado momento. Entre las formas de extinción del acto administrativo la doctrina distingue, por una parte la extinción normal del acto que puede provenir del cumplimiento de su objeto $^{1}$, de la operatividad de una cláusula accesoria, como el plazo o la condición. Y por otra, la extinción anormal como consecuencia del ejercicio de potestades reconocidas por el ordenamiento jurídico a la Administración para volver sobre los actos administrativos o sus efectos, por razo-

Bermúdez, Jorge (2011) Derecho Administrativo General. 2a edición. Santiago: Thomson Reuters, p. 129. 
nes de interés general o por motivos de legalidad, tales como la nulidad, la invalidación, la revocación y la caducidad. En efecto, se le reconocen a la Administración del Estado la existencia de potestades de autotutela declarativa que le permiten volver sobre sus actos administrativos en forma unilateral sin necesidad de acudir a los Tribunales de Justicia, con la finalidad de custodiar el principio de juridicidad ${ }^{2}$.

La extinción anormal de los actos administrativos ha sido acogida en términos parciales en la Ley No 19.880, de 2003 que establece las Bases de los Procedimientos Administrativos que rigen los Actos de la Administración del Estado, al regular expresamente, por una parte la potestad invalidatoria en el artículo $53^{\circ}$, y por otro lado la potestad revocatoria en el artículo $61^{\circ}$ respectivamente, aunque omite establecer reglas aplicables a la nulidad y a la caducidad.

En otro orden de ideas, de conformidad con el artículo $2^{\circ}$, el ámbito de aplicación de la Ley No 19.880 , de 2003, se extiende a cualquier órgano perteneciente a la Administración del Estado, confiriendo, en consecuencia, potestades amplias de revisión a todo órgano público para volver sobre sus actos administrativos por razones de legalidad, esto es, por vicios congénitos del acto mismo, o por razones externas de oportunidad, conveniencia o mérito ${ }^{3}$.

El presente trabajo tiene por objeto analizar específicamente la potestad revocatoria de los actos administrativos válidos, estructurando un concepto normativo unívoco para entender la naturaleza de la potestad regulada en el artículo 61 de la Ley No 19.880, de 2003, analizando su sentido, alcance, contenido y los límites a su ejercicio, de conformidad con lo establecido en la Ley No 19.880, de 2003.

\section{1) Potestades de ReTiRo De los ACTOS ADMinistrativos}

Los actos administrativos entendidos como declaraciones unilaterales de voluntad, de juicio, de conocimiento o de deseo realizadas por la Administración del Estado en el ejercicio de una potestad pública, tienen por objetivo natural producir efectos específicos respecto de las situaciones jurídicas de los particulares ${ }^{4}$, para crear, modificar, constatar, dicta-

2 Olguín, Hugo (1961) Extinción de los actos administrativos. Revocación, invalidación y decaimiento. Santiago: Editorial Jurídica de Chile, p. 34.

3 Cordero, Luis (2015) Lecciones de Derecho Administrativo. Santiago: Thomson Reuters, p. 314.

4 García de Enterría, Eduardo y Fernández, Tomás-Ramón (2011) Curso de Derecho Administrativo. $15^{\text {a }}$ edición. Pamplona: Thomson Reuters, t. I, p. 571. 
minar o extinguir relaciones jurídicas entre estos y la Administración ${ }^{5}$, materia que reviste el objeto mismo del acto administrativo ${ }^{6}$.

Generalmente desde el momento de la notificación o publicación, los actos administrativos son eficaces, esto es, están llamados a producir efectos jurídicos - positivos o negativos- sobre las situaciones jurídicas del destinatario, incorporando dichos efectos en su patrimonio, deviniendo en intangibles e inmodificables para la Administración Pública ${ }^{7}$, al quedar amparados bajo la garantía de derecho de propiedad, salvo que la Administración pueda despojar dichos derechos por medio de la potestad expropiatoria por utilidad pública o interés nacional con la debida indemnización del daño patrimonial efectivamente causado. De este modo, los actos administrativos desde el momento de su notificación o publicación adquieren una cierta estabilidad que limita o restringe las potestades de revisión de la Administración del Estado ${ }^{8}$.

No obstante, la estabilidad e intangibilidad de los actos administrativos, actualmente, se encuentra relativizada por la expresa regulación de potestades de retiro a favor de la Administración del Estado que le permiten volver sobre sus actos vigentes, invocando razones de mérito, conveniencia $u$ oportunidad o aduciendo vicios o errores jurídicos que afectan la legitimidad del acto administrativo. En efecto, la estabilidad de los actos administrativos se encuentra estrechamente vinculada con la procedencia de las potestades revocatorias e invalidatorias, que tienen por objeto principal conciliar, adaptar o hacer coherentes dichos actos con el interés general en un determinado tiempo y lugar o, ajustarlos al ordenamiento jurídico corrigiendo cualquier vicio de ilegitimidad.

Dentro de las potestades de retiro se encuentran dos figuras típicas, definidas y distinguibles entre sí. En primer lugar, nos encontramos con la potestad de retiro que tiene por objetivo sancionar los actos administrativos contrarios a derecho, eliminándolos del ordenamiento jurídico por razones de legitimidad, por la presencia de vicios que afectan su estructura interna, denominada invalidación. En segundo lugar, nos encontramos con la potestad de retiro cuyo ejercicio se ampara en el interés

García-Trevijano, José Antonio (1986) Los actos administrativos. Madrid: Civitas, p. 95. Aróstica, Iván (2013). "La actividad jurídica de la Administración del Estado". Revista de Actualidad Jurídica, Universidad del Desarrollo. No 28, p. 275.

Soto Kloss, Eduardo (1984). "Los derechos adquiridos en el Derecho Público Chileno. (Réquiem para una inepcia doctrinaria)”. Revista de Derecho y Jurisprudencia, 81, Derecho, pp. 18-19.

8 Aguerrea, Pedro (2003). "Las prerrogativas del acto administrativo en la Ley $\mathrm{N}^{\circ} 19.880$ ". AAVV., Ley $N^{\circ} 19.880$ sobre procedimientos administrativos. Santiago: conferencias Universidad Santo Tomás, p. 49. 
general, y que tiene por objetivo extinguir los efectos de los actos administrativos válidos que han devenido, en un determinado tiempo y lugar, en inconvenientes o inoportunos respecto de interés general, esta potestad recibe el nombre de revocación.

\section{2) Potestad invalidatoria Y ReVocatoria. Semejanzas Y DIFERENCIAS}

Hemos señalado que ambas potestades se insertan dentro de las formas anormales de extinción de los actos administrativos. Si bien en ambas potestades se asume que la Administración del Estado puede revisar un acto administrativo, tanto por la potestad invalidatoria como la potestad revocatoria, estas no son una manifestación específica -expresa o implícita- de la potestad originaria atribuida para dictar el acto administrativo. De este modo, no necesariamente el titular de la potestad para dictar actos administrativos será al mismo tiempo titular de la potestad de revisión o de retiro de la Administración.

Sin embargo, el legislador suele radicar tanto la potestad invalidatoria como la revocatoria en la misma autoridad que dictó el acto administrativo ilegítimo o aquel acto que ha devenido en inconveniente o inoportuno con el interés general ${ }^{9}$.

La potestad invalidatoria se considera como una manifestación de las potestades de autocontrol o autotutela de la Administración del Estado, entregada por el ordenamiento jurídico para un adecuado resguardo del principio de juridicidad para dar cumplimiento al deber de todos los órganos públicos de observar la Constitución y las normas dictadas conforme a ella, según lo dispuesto en el artículo 6 de la Carta Fundamental ${ }^{10}$. En este sentido, Ferrada considera que la potestad invalidatoria constituye un privilegio exorbitante de la Administración, para anular por sí misma un acto administrativo por concurrir un vicio o irregularidad invalidante sin necesidad de concurrir a los Tribunales de Justicia para obtener esa declaración ${ }^{11}$.

De este modo el privilegio de autotutela tiene como fundamento la protección del principio de legalidad, que le impone a la Administración

9 Bocanegra, Raúl (2005) Teoría del acto administrativo. Madrid: Iustel, p. 147.

10 Jara, Jaime (2004) La nulidad de derecho público ante la doctrina y la jurisprudencia. Santiago: Libromar, pp. 94-96.

11 Ferrada, Juan Carlos (2007). "La potestad invalidatoria de los órganos de la Administración del Estado" "AA.VV"., Acto y Procedimiento Administrativo. Actas de las Segundas Jornadas de Derecho Administrativo. Valparaíso: Edeval, p. 132. 
el deber de invalidar los actos contrarios a derecho con la finalidad de cautelar el ordenamiento jurídico ${ }^{12}$. En este sentido, Marín considera que la invalidación constituye un verdadero antibiótico de la juridicidad, por cuanto mediante la invalidación se administra un remedio enérgico a una grave patología de las actuaciones administrativas que infectan el ordenamiento jurídico. Reviste, en consecuencia, un medio de sancionar la irregularidad de los actos administrativos viciados, privándolos de sus efectos jurídicos ${ }^{13}$.

Dogmáticamente la invalidación se configura como un poder de la Administración del Estado para volver sobre sus actos de oficio o a petición de parte, con la finalidad de revisar y retirar por sí misma los actos administrativos viciados, irregulares o inconciliables con el ordenamiento jurídico - por adolecer de vicios de legalidad sustanciales- a través de un acto administrativo de signo contrario ${ }^{14}$. En efecto, la invalidez del acto administrativo se concibe como la inadecuación entre los elementos de este y las disposiciones jurídicas que han sido previstas por la norma habilitante para su emisión, cuando el acto carece de alguno de los requisitos exigidos por la norma legal, v.gr., un error de hecho ${ }^{15}$, violación de un precepto del ordenamiento jurídico o falta de motivos ${ }^{16}$.

Con la entrada en vigencia de la Ley No 19.880 , de 2003, se reconoció expresamente en el artículo 53 la potestad invalidatoria superándose la pugna doctrinal ${ }^{17}$ entre aquellos que negaban la autotutela administrativa y quienes asumían que la Administración estaba investida de la potestad anulatoria -un privilegio exorbitante- para proteger el principio de juridicidad ${ }^{18}$. Por su parte, quienes negaban la potestad invalidatoria,

Millar, Javier (2003). "La potestad invalidatoria en la jurisprudencia nacional. Procedencia, alcance y limitaciones". Revista de Derecho, Universidad Austral de Chile, XIV, pp. 8398.

13 Marín Vallejo, Urbano (2000). "Vigencia actual de la invalidación de los actos administrativos". Revista de Derecho del Consejo de Defensa del Estado, No 1, pp. 48-49.

14 Millar, Javier (2000). La potestad invalidatoria en el Derecho chileno. Tesis Doctoral [inédita], Universidad de Chile, p. 8.

15 Vargas Zincke, Osvaldo (1995). "Algunos aspectos sobre la invalidación en la jurisprudencia de la Contraloría General de la República”. Gaceta Jurídica, N 178, p. 37.

16 Baca Oneto, Víctor (2006) La invalidez de los contratos públicos. Pamplona: Civitas, p. 39.

17 Huepe Artigas, Fabián (2013). "El principio de irretroactividad de los actos administrativos como límite a la potestad invalidatoria de la Administración”. En Bocksang Hola, Gabriel y Lara Arroyo, José Luis (Coordinadores): Procedimiento administrativo y contratación pública. Santiago: LegalPublishing, pp. 147-177. Sото KLoss, Eduardo (2014). "Inestabilidad del acto administrativo y derecho de los destinatarios (A propósito del artículo 53 inciso $1^{\circ}$ de la Ley $\mathrm{N}^{\circ} 19.880$ )". En Soto Kloss, Eduardo (Coordinador): Administración y Derecho. Santiago: Thomson Reuters, pp. 283-297.

18 Letelier Wartenberg, Raúl (2014). "Contra la confianza legítima como límite a la invalidación de actos administrativos". Revista Chilena de Derecho, Volumen 41, N 2, pp. 609- 
argumentaban que la Administración carecía de autotutela para volver sobre sus actuaciones pasadas cuando los efectos del acto habían sido adquiridos de buena fe e incorporados en el patrimonio del destinatario ${ }^{19}$, porque no era legítimo que el particular soportase los errores de la Administración. En consecuencia, la Administración para invalidar legalmente un acto administrativo aparentemente viciado debía acudir a los Tribunales Ordinarios de Justicia, mediante la acción de nulidad de derecho público ${ }^{20}$.

Empero, el artículo 53 de la Ley No 19.880, de 2003 reguló la potestad invalidatoria en sus aspectos formales o procedimentales sobre los actos administrativos contrarios a derecho, exigiendo, por una parte la realización de una audiencia previa que ha sido elevada jurisprudencialmente a la categoría de requisito esencial ${ }^{21} \mathrm{y}$, por otra, que la potestad sea ejercida dentro del plazo de 2 años desde la notificación o publicación del acto administrativo ${ }^{22}$. Sin embargo, el artículo 53 no reguló los aspectos esenciales de la potestad invalidatoria, tampoco los vicios del acto administrativo contrario a derecho ni los límites sustanciales para la protección de las situaciones jurídicas consolidadas emanadas de los actos administrativos viciados. No obstante, parte de la doctrina ${ }^{23}$ seguida en forma incipiente por la jurisprudencia han acudido al principio de confianza legítima para limitar el potencial ejercicio abusivo de la potestad invalidatoria $^{24}$.

\section{4.}

19 Soto Kloss, Eduardo (1996). Derecho Administrativo. Bases fundamentales. Santiago: Editorial Jurídica de Chile, t. II, p. 211. Aróstica, Iván (1984). "La extinción de los actos administrativos y la jurisprudencia reciente de los tribunales de justicia”. Revista Chilena de Derecho, $\mathrm{N}^{\circ} 11$, p. 437.

20 Bermúdez (2011) 137.

21 La Corte Suprema ha sentenciado que la audiencia previa, ostenta el carácter de trámite esencial, “(...) a la Corporación Nacional Forestal le resulta aplicable lo dispuesto en el artículo 53 de la Ley $N^{\circ} 19880$, en virtud del cual para adoptar la decisión de invalidación debe existir audiencia previa del interesado. La falta de este trámite esencial, permite calificar de ilegal el acto terminal del procedimiento que se llevó a efecto (...)”. Corte Suprema, 26 de octubre de 2009, Rol No 2246-2009. También, Corte Suprema, 21 de septiembre de 2009, Rol N6014-09.

22 La Corte Suprema dispuso que: “(...) la invalidación está expresamente reglamentada en el artículo 53 de la Ley $N^{\circ} 19.880$, la cual presenta las limitaciones contenidas en esa misma disposición, esto es, que se realice previa audiencia del afectado y dentro del término de dos años contados desde la notificación o publicación del acto". Corte Suprema, 18 de octubre de 2011, Rol N4437-2011.

23 Bermúdez, Jorge (2005). "El principio de confianza legítima en la actuación de la Administración como límite a la potestad invalidatoria”. Revista de Derecho de la Universidad Austral de Chile, XVIII, No 2, pp. 83-105.

24 Corte Suprema, 27 de octubre de 2005, Rol No 5.202-05. 
La potestad revocatoria también ha sido regulada en la Ley No 19.880 en el artículo 61, pero con una evidente ausencia de densidad normativa. Tal precepto solo dispone -en términos generales- que los actos administrativos podrán ser revocados por el órgano que los hubiere dictado, limitándose el ejercicio de la potestad revocatoria, en primer lugar, en contra de los actos administrativos declarativos o creadores de derechos adquiridos legítimamente, en segundo lugar, en el caso que la ley haya determinado expresamente otra forma de extinción de los actos administrativos y, finalmente, cuando la naturaleza de la regulación legal impida que el acto sea dejado sin efecto.

No obstante, con la regulación actual de la potestad revocatoria el legislador no permite al operador jurídico comprender el objetivo regulatorio del artículo 61, atendido que en principio la ley solo efectuaría una habilitación competencial de carácter general a los órganos de la Administración del Estado para volver sobre sus actos administrativos y dejarlos sin efecto, respetando la prohibición legal de no invocar la revocación por sobre formas específicas de extinción de los actos administrativos, y de respetar los derechos adquiridos legítimamente provenientes de actos declarativos o constitutivos. Claramente, el legislador no provee mayores antecedentes sobre el ejercicio de la potestad revocatoria, no regula un concepto unívoco de revocación ni determinó específicamente su objeto, causales ni los límites de esta potestad pública.

Dogmáticamente la revocación se concreta en una resolución administrativa destinada a poner término a los efectos jurídicos producidos por un acto administrativo regular, cuando la Administración estima conveniente hacerlo cesar por exigirlo el interés general. De este modo, la clave de la potestad revocatoria estriba en la tensión que se origina entre el interés público que exige la modificación de una situación jurídica existente y la seguridad jurídica del particular sobre la mantención de su statu quo intangible, derivado de la regularidad jurídica del acto administrativo que se pretende revocar.

Ahora bien, cabe preguntarnos sobre cuál es la noción de revocación que adopta el artículo 61 de la Ley No 19.880, si el concepto de revocación de dicho precepto constituye la regla general que informa el ejercicio de esta potestad siendo la única forma que ostenta la Administración para revisar los efectos del acto administrativo, o si simplemente reviste el carácter de una norma de base que atribuye la potestad revocatoria a todos los órganos de la Administración del Estado, no obstante que pueden existir reglas especiales que regulen manifestaciones específicas de la potestad administrativa que le permiten a la Administración del Estado vol- 
ver sobre los actos administrativos válidos por razones de interés general. En otras palabras, se trata de determinar cuál es el concepto de revocación del artículo 61 de la Ley No 19.880, de 2003, su aplicación general al resto del ordenamiento jurídico, requisitos de procedencia y límites.

\section{3) ANÁlisis ESPECÍfICO DEL ARTículo 61 DE LA LEY No 19.880, DE 2003}

Tal como hemos afirmado, el artículo 61 regula la potestad revocatoria por exclusión, porque comienza por consagrar una habilitación general a todos los órganos de la Administración del Estado que les permite revocar sus actos administrativos, y posteriormente continúa con una delimitación conceptual al excluir la procedencia de esta potestad ante actos administrativos constitutivos o declarativos de derechos, o en aquellos casos que el legislador prevea una forma de extinción diferente del acto administrativo. Empero, la Ley No 19.880, de 2003 no regula el objeto ni el contenido de la potestad revocatoria. Ante este panorama, es preciso acudir a la doctrina y a la jurisprudencia, a fin de establecer un concepto general, determinar cuáles son los requisitos de procedencia y límites de la potestad revocatoria.

\section{(3.1.) CONCEPTO DE REVOCACIÓN EN LA LEY No 19.880, DE 2003}

Si bien el artículo 61 solo establece una habilitación competencial, la doctrina ha entendido que la revocación consiste en el retiro de los actos administrativos válidamente emitidos por razones de mérito oportunidad o conveniencia, esto es, la remoción voluntaria de un acto administrativo válidamente emitido cuyos efectos son inoportunos o inconvenientes por ser contrarios al interés público ${ }^{25} \mathrm{o}$ a la buena administración ${ }^{26}$.

Nuestra jurisprudencia judicial entiende la potestad revocatoria como aquella destinada a derogar o dejar sin efecto un acto administrativo por razones de mérito, oportunidad o conveniencia:

“(...) ante nuevos escenarios fácticos o necesidades públicas cambiantes, aparece razonable dotar a la Administración de una especial potestad revocatoria que sea de su exclusiva y discrecional competencia, a fin de eliminar los efectos inconvenientes o inoportunos de un acto administrativo"27.

\footnotetext{
25 Olguín (1961) 61.

26 Iribarren, Juan Antonio (1936). Lecciones de Derecho Administrativo. Santiago: Nascimento, p. 161.

27 Corte Suprema, 23 de junio de 2011, Rol No 6379-2011.
} 
El profesor español de Derecho Administrativo, Eduardo García de Enterría entiende por revocación la retirada definitiva por la Administración de un acto suyo anterior mediante otro de signo contrario ${ }^{28}$. Por su parte, en nuestro medio el profesor Silva Cimma concibe la revocación como la medida que adopta la propia Administración Activa tendiente a dejar sin efecto un acto administrativo por causa de mérito, oportunidad o conveniencia, es decir, cuando la ponderación del bien común así lo aconseja. Para este autor, la potestad revocatoria tiene su fundamento en el poder jurídico que tiene el órgano emisor para volver sobre sus actos y extinguirlos, mediante actos administrativos de contrario imperio ${ }^{29}$.

Como se puede apreciar, la potestad revocatoria lleva envuelta un desajuste o incompatibilidad entre el interés general que debe ser apreciado por la Administración del Estado, a fin de determinar la evolución de las necesidades públicas en un momento determinado, y la finalidad específica de un acto administrativo, que precisamente por el cambio de circunstancias deviene en inoportuno, inconveniente o carente de mérito. A diferencia de la invalidación, el ejercicio de la potestad revocatoria lleva envuelta consideraciones de interés público en un determinado momento y bajo ciertas condiciones.

También la revocación ha sido entendida desde una óptica meramente subjetiva, como el simple retiro de un acto administrativo por medio de un acto posterior emanado de la Administración sin un mayor análisis de las causas de extinción del acto administrativo. Marienhoff, concibe la revocación como la extinción de un acto administrativo dispuesta por la propia Administración Pública para satisfacer actuales exigencias del interés público o para restablecer el imperio de la legitimidad ${ }^{30}$. Por su parte, Soto Kloss afirma que no es necesario distinguir -con el objeto de delimitar su sentido y alcance- entre revocación e invalidación, por cuanto la revocación no es más que una antijuridicidad sobreviniente del acto administrativo por cambio de circunstancias, sean de hecho, sean de derecho ${ }^{31}$.

La visión subjetiva conceptualiza la revocación como una forma general de extinción o de retiro de los actos administrativos, distinguiendo una extinción por razones de mérito o de conveniencia y, una por razones de legalidad o legitimidad. Esta posición, se relaciona con aquella sus-

\footnotetext{
28 García de Enterría (2011) 681.

29 Silva Cimma, Enrique (1995). Derecho Administrativo Chileno y Comparado. Actos, contratos y bienes. Santiago: Editorial Jurídica de Chile, p. 154.

30 Marienhoff, Miguel (1993). Tratado de Derecho Administrativo. 4 a edición. Buenos Aires: Abeledo-Perrot, t. II, p. 577.

31 Soto Kloss, Eduardo (1989). "Invalidación de los actos administrativos". Revista Chilena de Derecho, Volumen 16, $\mathrm{N}^{\circ}$ 2, pp. 477-478, nota no 6. En el mismo sentido, BoquerA Oliver, José María (1977). La irrevocabilidad de los actos administrativos. Madrid: Moneda y Crédito, p. 165.
} 
tentada por parte de la doctrina extranjera que afirma, que si el retiro es dispuesto en sede administrativa corresponde hablar de revocación, con independencia que se invoquen razones de legalidad o de oportunidad, mientras que, si opera el retiro en sede judicial, se habla de anulación solo por vicios de legalidad ${ }^{32}$.

Por último, la revocación ha sido entendida como una sanción administrativa especial ante los incumplimientos específicos del destinatario de un acto administrativo favorable. En este sentido, Cordero Vega habla de revocaciones rescisorias para referirse a aquella privación de efectos de un acto administrativo de contenido favorable, como consecuencia que su destinatario ha incurrido en una conducta ilegal o contraria a las obligaciones que el acto impone ${ }^{33}$. En el mismo sentido, Laguna de Paz señala que el incumplimiento se configura como una infracción a las normas que regulan una determinada actividad, cuya respuesta sancionadora que se instrumentaliza a través del procedimiento sancionador, que tiene por objeto revocar el acto administrativo habilitante conjunta e independientemente de la sanción pecuniaria respectiva ${ }^{34}$.

Una clara manifestación de esta especie de potestad revocatoria se puede identificar en materia educacional donde la legislación correspondiente le entrega al Ministro de Educación con acuerdo del Consejo Nacional de Educación, la potestad de revocar el reconocimiento oficial entregado a los establecimientos educacionales para que puedan impartir en forma válida y autónomamente un determinado tipo de educación y percibir fondos públicos por la vía de subvenciones, de conformidad con los artículos 73 y 74 de la Ley $N^{\circ} 20.529$, de 27 de agosto de 2011.

Una situación similar se puede encontrar en materia de telecomunicaciones, donde en virtud del artículo 28 de la Ley $\mathrm{N}^{\circ} 18.168$, de 2 de octubre de 1982, General de Telecomunicaciones, se facultad a la Subsecretaría de Telecomunicaciones para revocar las concesiones de telecomunicaciones cuando el concesionario hubiere incurrido sin causa justificada en la interrupción de la explotación del servicio de telecomunicaciones por el plazo de 3 meses.

\section{(3.2.) SUJETO ACTIVO DE LA REVOCACIÓN ADMINISTRATIVA}

La revocación es una potestad que se manifiesta en un acto administrativo de signo contrario con aquel acto administrativo que ha devenido

\footnotetext{
32 Cassagne, Juan Carlos (1974). El acto administrativo. 2a edición. Buenos Aires: Abeledo Perrot, p. 380-381.

33 Cordero (2015) 315.

34 Laguna de Paz, José Carlos (2006). La Autorización Administrativa. Navarra: Thomson Civitas, pp. 354-356.
} 
en inoportuno o inconveniente, por ende, el acto revocatorio tiene los mismos elementos, presupuestos y características de toda declaración jurídica unilateral de la Administración del Estado ${ }^{35}$. En sentido, el sujeto activo de la revocación es un órgano de la Administración dotado de potestades específicas para volver sobre sus actos administrativos válidos por razones de mérito, oportunidad o conveniencia. Explícitamente el legislador en el artículo $61^{\circ}$ de la Ley No 19.880 , se encargó de precisar que el órgano titular de la potestad revocatoria es el mismo que dictó el acto que se pretende revocar ${ }^{36}$.

A diferencia de la potestad invalidatoria, se reconoce que la revocación administrativa constituye una manifestación específica de la apreciación del interés general en un momento determinado, que el legislador le entrega en forma exclusiva y excluyente a los órganos administrativos, para que a través del ejercicio de la potestad revocatoria aprecien y califiquen la vigencia de un determinado acto administrativo frente a los cambios de circunstancias que lo convierten en incompatible con el interés general.

\section{(3.3.) OBJETO DE LA REVOCACIÓN ADMINISTRATIVA}

Mediante el ejercicio de la potestad revocatoria se extinguen los efectos jurídicos de los actos administrativos válidos, esto es, los derechos y obligaciones nacidos de estos actos. El objeto de la revocación no es restaurar la legitimidad violada, sino atender a la conveniencia administrativa, por cuanto la revocación no supone confrontar el acto administrativo desde el punto de vista del principio de juridicidad o de legalidad, sino que implica someterlo al criterio subjetivo de la propia Administración que se encarga de confrontar el acto administrativo con una nueva calificación del interés general, esto es, la conveniencia de otorgar un nueva regulación ante necesidades públicas cambiantes ${ }^{37}$.

Uno de los aspectos más relevantes sobre el objeto de la revocación, dice relación con la legitimidad del acto administrativo, atendido que este fue dictado para satisfacer las necesidades públicas de un determinado momento, fruto de la apreciación particular de los motivos fácticos y

35 Salas Arquer, José Manuel (1974). La revocación de los actos administrativos en el Derecho Español. Madrid: Instituto de Estudios Administrativos, p. 27.

36 Bandeira de Mello, Celso (2006). Curso de Derecho Administrativo. México D.F: Porrúa, p. 390.

37 Moraga Klenner, Claudio (2010). "La Actividad formal de la Administración del Estado". En Pantoja Bauzá, Rolando, (Coordinador): Tratado de Derecho Administrativo, Santiago: LegalPublishing, t. VII, p. 258. 
jurídicos que sirven de causa al acto administrativo. De este acto administrativo válido emanan derechos y obligaciones, que se insertan en una relación jurídica válida. Sin embargo, ante el cambio en la apreciación del interés general en un momento específico, los efectos del acto administrativo no comulgan con el interés público, por razones de mérito, conveniencia u oportunidad.

La validez del acto administrativo objeto de la revocación trae como consecuencia natural que la potestad revocatoria no se dirija en contra del acto administrativo, sino sobre sus efectos que por una nueva apreciación del interés general han devenido en inoportunos o inconvenientes. Ello implica que la potestad revocatoria se dirige exclusivamente sobre actos administrativos aptos para producir efectos jurídicos subsistentes en el tiempo, descartando su procedencia en contra de actos administrativos certificatorios o actos administrativos cuyos efectos son de carácter instantáneo ${ }^{38}$.

Claramente, tratándose de actos administrativos de efectos instantáneos o de actos administrativos cuyos efectos se han agotado o consumado en el tiempo ${ }^{39}$, invocar la potestad revocatoria no es procedente, por cuanto no existen efectos jurídicos que se opongan al interés general, y que merezcan ser revocados por la autoridad administrativa. Más bien, la revocación opera de manera normal donde existen actos administrativos cuyos efectos se cumplen sucesivamente en el tiempo al devenir en inoportunos o inconvenientes ${ }^{40}$.

Atendido que la revocación procede sobre los efectos de los actos administrativos válidos es determinante identificar el carácter favorable o perjudicial de los mismos sobre el patrimonio del destinatario del acto, con el propósito de diagnosticar el impacto temporal de la revocación sobre los derechos adquiridos. De este modo, es relevante precisar si la potestad revocatoria alcanza los efectos ya producidos de los actos administrativos o solo se extiende a los efectos preexistentes de las relaciones jurídicas nacidas bajo el imperio de una nueva apreciación del interés general.

Sobre el particular se ha afirmado que la potestad revocatoria tiene un ámbito de aplicación limitado, por cuanto la inoportunidad, la inconveniencia o la falta de mérito solo alcanza los efectos subsistentes del acto administrativo que colisionan o no comulgan con la nueva apreciación del interés general. De este modo, el ataque revocatorio deja incólume

\footnotetext{
38 Olguín (1961) 133.

39 García-Trevijano Fos, José Antonio (1986). Los actos administrativos. Madrid: Civitas, p. 431.

40 Moraga (2010) 258.
} 
los efectos ya transcurridos, pero la relación jurídica no prosigue ${ }^{41}$, por lo tanto los efectos generados o causados por el acto administrativo revocado subsisten en plenitud, en tanto regulares y válidos frente al contenido del acto administrativo revocatorio ${ }^{42}$.

\section{(3.4.) MOTIVO DE LA POTESTAD REVOCATORIA}

El motivo o causa de la revocación dice relación con la inconveniencia, inoportunidad o carencia de mérito de los efectos jurídicos derivados de un acto administrativo válido respecto del interés público, es decir, el resultado de una nueva apreciación sobre una determinada situación que tiene como conclusión una inadecuación de la misma con el interés público. Ello es consecuencia de un juicio realizado hoy sobre lo que se produjo antes, determinando que la decisión tomada antaño no conviene en la actualidad a los intereses administrativos ${ }^{43}$.

De este modo, el motivo o causa del ejercicio de la potestad revocatoria debe dar cuenta de la mutación sobreviniente de uno de los presupuestos del acto administrativo original, esto es, la modificación del interés público que debe satisfacer la Administración del Estado. Cabe señalar, que el acto administrativo resulta inadecuado porque fueron mal apreciadas las circunstancias y el interés general en el mismo momento de su emisión. También resulta inoportuno porque en un momento sucesivo esas circunstancias y necesidades generales experimentan una modificación que torna el acto administrativo no conforme con el fin perseguido ${ }^{44}$.

Laguna de Paz afirma que los efectos de los actos administrativos pueden verse modificados por cambios normativos, cuando se exceden los límites del deber de adaptación. Por un nuevo criterio de apreciación, que se concreta en una distinta valoración de la conveniencia del mantenimiento del acto administrativo. Por cambios de circunstancias objetivas de índole externa a la Administración. Y también, cuando el cambio de circunstancia se haya producido de manera imprevista, por una imposi-

Bandeira de Mello (2006) 391.

Caldera Delgado, Hugo (2001). Tratado de Derecho Administrativo. Santiago: Ediciones Parlamento, t. II, p. 124.

Bandeira de Mello (2006) 393.

Díez, Manuel María (1956). El acto administrativo, Buenos Aires: Tipográfica Editora Argentina, p. 242 . 
bilidad sobrevenida, cuando el contenido del acto administrativo resulta imposible llevarlo a cabo ${ }^{45}$.

\section{(3.5.) FUNDAMENTO NORMATIVO DE LA REVOCACIÓN ADMINISTRATIVA}

En cuanto al fundamento normativo de la potestad revocatoria, es preciso señalar que el acto administrativo revocatorio se debe basar en una norma jurídica que habilite a la autoridad administrativa para extinguir los efectos jurídicos de un acto administrativo válido, regular, eficaz tanto para su titular como para terceros.

Normalmente se considera que el fundamento de la potestad revocatoria, emana de la misma norma competencial que habilita a un órgano administrativo para dictar aquellos actos administrativos que posteriormente serán objeto del ejercicio de la potestad revocatoria, acogiendo el principio que las cosas se deshacen de la misma forma como se hacen.

Lo anterior merece ser precisado, por cuanto en nuestro ordenamiento jurídico no existen competencias implícitas, atendido que el artículo 7 inciso $2^{\circ}$ de la Carta Fundamental exige que las potestades deben ser expresamente atribuidas por la Constitución o la ley, no siendo procedente que autoridad alguna ni aun a pretexto de circunstancia extraordinaria ostentar más potestades que las expresamente conferidas. Este mandato se cumple con la regulación explícita en el artículo 61º de la Ley No 19.880 de la potestad revocatoria. De este modo, el órgano público que dictó el acto administrativo original -que se pretende revocar- no necesariamente se encuentra investido de la potestad revocatoria, por cuanto es el legislador quien determina la atribución expresa de potestades, pudiendo radicar la potestad revocatoria en una autoridad distinta, por ejemplo en el superior jerárquico o en otra autoridad independiente que aporta su autorización para revocar ${ }^{46}$.

En este sentido la potestad revocatoria goza de una amplia discrecionalidad, por cuanto queda al arbitrio del órgano público competente ponderar el momento u oportunidad para revocar el acto administrativo, de conformidad con los criterios de conveniencia u oportunidad ${ }^{47}$, teniendo como parámetro la alteración que ha sufrido el interés público.

\footnotetext{
45 Laguna de Paz (2006) 334-343. En un sentido similar se ha pronunciado la Corte Suprema, que avala la procedencia de la potestad revocatoria por cambios evidentes de orientación de la actuación administrativa, más que por mérito u oportunidad. Corte Suprema, 18 de mayo de 2009, Rol No 2.614-2009.

46 Olguín (1961) 105.

47 BERMÚdEZ (2011) 141.
} 
Al respecto, Fortes Martín entiende que:

"(...) la clave de la potestad revocatoria de la Administración se encuentra en la tensión que se origina entre, por un lado, el interés público a la modificación o revocación de la situación existente $y$, de otro lado, la seguridad juridica del particular al mantenimiento de su statu quo intangible, aspecto este que, tradicionalmente, se ha venido sustentando en el ya mencionado principio de irrevocabilidad de los actos (.-) el fin último de la revocación de todo acto administrativo vendrá determinado por una motivación externa traducida en un interés público; interés público que sirve de fundamento a la revocación y que puede responder o no a las mismas razones de interés público que tuvo en cuenta inicialmente la Administración para dictar el acto cuya revocación ahora pretende ${ }^{348}$.

Por último, en algunos casos la potestad de revocar es incorporada por la Administración del Estado como una cláusula accesoria del acto administrativo, de manera tal que incumpliéndose una determinada obligación, la Administración Pública puede declarar ante sí y para sí la revocación de un acto administrativo. Ello es tolerable normativamente, pero con la salvedad que la mera inserción de una reserva de revocación en un acto administrativo no surtirá el efecto de enervar la irrevocabilidad del mismo, a menos que exista una ley que respalde dicha medida, por cuanto la revocación supone un plus de gravamen, necesitado siempre de respaldo legal ${ }^{49}$.

\section{(3.6.) EFECTOS DE LA REVOCACIÓN ADMINISTRATIVA}

Como hemos explicado, la revocación tiene por objeto suprimir o extinguir los efectos jurídicos de un acto válido que sean indeseados o no compatibles con el interés público en un determinado momento. Sobre el particular, surgen algunas interrogantes relacionadas con los límites y alcances de las consecuencias de la potestad revocatoria en el ámbito temporal y su impacto sobre las situaciones jurídicas favorables tanto del destinatario del acto administrativo revocado como de los terceros de buena fe.

Una primera aproximación consiste en determinar el momento a partir del cual se producen los efectos del acto administrativo revocatorio. Siguiendo la regla general de la vigencia de los actos administrativos en

\footnotetext{
48 Fortes Martín, Antonio (2006). "Estudio sobre la revocación de los actos administrativos". Revista de Derecho de la Universidad Austral de Chile, XIX, No 1, pp. 152-153.

49 Bocanegra Sierra, Raúl (2004) Lecciones sobre el acto administrativo. 2a edición. Madrid: Civitas, p. 219.
} 
el tiempo, el artículo 45 de la Ley $\mathrm{N}^{\circ} 19.880$ dispone que los efectos del acto revocatorio se producen desde el momento de su notificación, dejando incólumes las situaciones jurídicas creadas como consecuencia del acto revocado.

Ello, atendido que por una parte el acto revocatorio es de carácter desfavorable, y por aplicación del artículo 52 de la misma ley, solo puede disponer para el futuro, mientras, que por otra, el acto administrativo revocado goza de presunción de legalidad, correspondiendo a quien invocó su extinción destruir la presunción de legalidad, según el artículo $3^{\circ}$ de la Ley No 19.880 .

Ahora bien, en cuanto a la vigencia temporal de la revocación son las situaciones jurídicas posteriores a la notificación del acto revocatorio las que se ven alcanzadas por esta clase de extinción sobreviniente fundada en razones de mérito, conveniencia u oportunidad, por las divergencias entre los efectos del acto y el interés general en razón de una distinta valoración de las mismas circunstancias de hecho que dieron origen al acto administrativo, con la limitación estricta de no afectar los derechos emanados de los actos administrativos declarativos o constitutivos.

Una segunda aproximación, se puede plantear respecto de los actos administrativos favorables que el artículo $61^{\circ}$ de la Ley $\mathrm{N}^{\circ} 19.880$, de 2003 regula como una excepción sustantiva sobre el ejercicio de la potestad revocatoria, consagrando un verdadero principio de irrevocabilidad de los actos administrativos declarativos o constitutivos de derechos adquiridos legítimamente, con el objeto de equilibrar la revisión de los actos administrativos con la seguridad jurídica y la intangibilidad patrimonial de los derechos administrativos otorgados ${ }^{50}$.

Bajo este entendido, la Corte Suprema en uno de los pocos fallos que han profundizado sobre la potestad revocatoria, dispuso que:

"(...) para estar frente a derechos adquiridos, es necesario que el particular tenga la facultad de exigir que su situación sea respetada y que la Administración tenga la obligación de respetarla, de manera tal que si se encuentra autorizada la revocación, no puede hablarse de derechos adquiridos; (.-) Que, en efecto, la disponibilidad de los efectos del acto por parte de la Administración es un requisito esencial para la revocación" 51 .

A nuestro entender este fallo incurre en una explicación compleja de algo evidente. Empero, para que proceda la revocación debe existir la

\footnotetext{
50 Almeida Cerrera, Marcos (2010) "El principio de irrevocabilidad de los actos favorables". En Santamaría Pastor, Juan Alfonso (Director): Los principios juridicos del Derecho Administrativo. Madrid: La Ley, p. 1106.

51 Corte Suprema, 23 de junio de 2011, Rol No 6379-2009.
} 
posibilidad que la Administración pueda disponer de los efectos del acto administrativo, y esto solo ocurrirá -por mandato expreso del artículo 61- en el caso de actos administrativos de carácter desfavorables, o cuyos efectos sean diferidos o de tracto sucesivo, excluyendo a los actos administrativos certificatorios o de constancia. De este modo, en el caso de los actos administrativos favorables los órganos públicos deben respetar los derechos adquiridos legítimamente, se trata de un efecto erga omnes del acto favorable. No existe disponibilidad de los efectos de los actos favorables, salvo que el acto adoleciera de vicios de legalidad, materia que es propia del artículo 53 que consagra la potestad invalidatoria.

Una tercera aproximación dice relación con las revocaciones especiales, que regula el ordenamiento jurídico en ámbitos sectoriales donde se realizan actividades económicas bajo un régimen de autorización administrativa. Por ejemplo, en el caso de los establecimientos educacionales que funcionan bajo un régimen de reconocimiento oficial, los servicios sanitarios, los servicios de telecomunicaciones que funcionan bajo un régimen de concesión, o en materia de concesiones provisionales de plantas productoras de gas, la revocación elimina los efectos del acto administrativo, pero también priva a los sujetos cualificados de seguir ejerciendo la actividad autorizada o concedida, estableciendo inhabilidades temporales o perpetuas para explotar la actividad económica específica. A modo ilustrativo, en materia de concesiones eléctricas la revocación de la concesión no responde a un cambio de criterio de la autoridad administrativa, ni a la falta de mérito u oportunidad, sino que la revocación se encuentra asociada al incumplimiento de una obligación específica del concesionario, adquiriendo la naturaleza de una verdadera sanción administrativa, una especie de revocación-sanción, consagrada en los artículos 15 y $16 \mathrm{~N}^{\circ} 3$ de la Ley $\mathrm{N}^{\circ} 18.410$, de 22 de mayo de 1985, que crea la Superintendencia de Electricidad y Combustibles.

\section{4) LIMITACIONES A LA POTESTAD REVOCATORIA}

La potestad revocatoria se mueve en el ámbito de la eficacia de los actos administrativos válidos, determinando la permanencia o disponibilidad de sus efectos jurídicos - derechos y obligaciones- en el patrimonio del particular titular de situaciones jurídicas de beneficio. Bajo este entendido es significativo identificar las limitaciones impuestas por el legislador, la jurisprudencia y la doctrina al ejercicio de la revocación administrativa, a fin de diagnosticar si ante la potestad revocatoria son respetados los derechos válidamente incorporados en el patrimonio del destinatario, 
intocables e intangibles en virtud de razones de seguridad jurídica y predictibilidad de las decisiones administrativas.

En una primera aproximación se detecta que la Ley No 19.880, de 2003 se encarga de regular límites sustanciales aplicables al ejercicio de la potestad revocatoria, vedando la revocación de los actos favorables de los cuales se desprenden derechos administrativos subjetivos ${ }^{52}$. Ello, ocurre cuando la Administración del Estado reconoce situaciones preexistentes -mediante actos declarativos de derechos- o, cuando crea ex novo situaciones jurídicas -al amparo de actos administrativos constitutivos de derechos- sobre actividades previamente vedadas a los particulares, v. gr., concesiones sobre bienes nacionales de uso público, concesiones de obra pública, concesiones eléctricas, etc.

No obstante, la potencia de la prohibición de la potestad revocatoria de avocarse a la revisión de los actos administrativos declarativos o constitutivos de derechos adquiridos legítimamente, la Ley No 19.880 omitió pronunciarse sobre los límites adjetivos o procedimentales que debería observar la autoridad competente para proceder a extinguir actos administrativos por razones de mérito, oportunidad o conveniencia, incurriendo en una afectación de las reglas de un debido, racional y justo procedimiento administrativo. En efecto, la ley no regula ninguna norma procedimental mínima de audiencia previa -salvo las reglas básicas de la notificación de los actos administrativos- que permitan a los particulares argumentar y fundamentar la conveniencia en la mantención del acto administrativo válido ${ }^{53}$, cuestión que en materia de invalidación ha sido elevado jurisprudencialmente a un trámite esencial.

Una segunda aproximación da cuenta que el estatuto de la revocación administrativa no precisa, por una parte la procedencia, límites y alcances de la potestad revocatoria sobre los actos administrativos desfavorables o perjudiciales para los particulares. Mientras, que por otra parte, tampoco el legislador determina la forma de coordinar, articular o relacionar la presencia de la revocación administrativa del artículo 61 de la ley de bases con otras formas específicas de extinción de los actos administrativos, optando prima facie por instaurar la regla que lo particular y específico primaría por sobre lo general, según se desprende de la letra b)

52 Morón Urbina, Juan Carlos (2011) "La revocación de actos administrativos, interés público y seguridad jurídica”. Revista Derecho PUCP, No 67, p. 425.

53 Así, por ejemplo en materia disciplinaria de funcionarios públicos, la Contraloría General de la República en el Dictamen N³5.081, de 2014, ha instaurado la tendencia de limitar la procedencia de la potestad revocatoria solo a los actos administrativos totalmente tramitado, impidiendo invocar esta potestad con posterioridad. 
del artículo 61, por cuanto no procede la revocación ante formas de extinción administrativas específicas.

\section{(4.1.) ACtos DEClarativos O CREAdores DE DERECHOS ADQUIRIDOS LEGÍTIMAMENTE}

El legislador dispuso que el ejercicio de la potestad revocatoria no alcanza, no es procedente, se encuentra prohibida y marginada respecto de los actos administrativos declarativos o constitutivos de derechos adquiridos legítimamente, impidiendo que los derechos reconocidos o constituidos, que hayan ingresado al patrimonio del destinatario sean disponibles para la Administración del Estado.

Entre las razones que justifican esta limitación sustancial a la potestad revocatoria, según Fernández de Velasco se pueden encontrar al menos dos. En primer lugar, el principio general de que nadie puede ir en contra de sus propios actos, quedando obligado a respetarlos en su integridad y a las consecuencias que emanan del mismo. En segundo lugar, la fundamentación que esta clase de limitación se relaciona con el propio concepto de acto administrativo que en algunos casos efectúa declaraciones que adquieren el valor de un derecho subjetivo, el cual viene protegido por el mismo acto administrativo que le sirvió de base; luego si cupiera la revocación, el nuevo acto administrativo habría desconocido la situación jurídica creada por el anterior revocado produciéndose el peligro de la inestabilidad en aquellas situaciones jurídica de origen administrativo $^{54}$.

Ello permite poner de relieve el hecho indudable que la determinación concreta de situaciones favorables para los particulares, no puede nunca ignorarse mediante una calificación a priori, en atención a que la mayor parte de los actos administrativos, incluso los no declarativos de derechos pueden producir perjuicios a los propios destinatarios o a terceros, perjuicios que deben ser protegibles, igual que los considerados como favorables o declarativos de derecho. Lo anterior justificaría que el límite a la libre revocabilidad vendría a ser el mismo, esto es, la protección de las situaciones de ventajas que del acto administrativo han podido surgir ${ }^{55}$.

Cabe hacer presente, que la dualidad entre actos favorables y actos desfavorables, no siempre suele presentarse en términos lineales ni puros,

\footnotetext{
54 Fernández de Velasco, Recaredo (1929) El acto administrativo. Madrid: Librería General de Victoriano Suárez, pp. 261-262.

55 Bocanegra Sierra, Raúl (1977) La Revisión de Oficio de los Actos Administrativos. Madrid: Instituto de Estudios de la Administración Local, pp. 253-254.
} 
sino que en muchos casos los actos de beneficios viene acompañados de deberes, cargas u obligaciones asociadas que condicionan el ejercicio y la vigencia de la situación de beneficio, v.gr., un permiso de edificación sujeto a la obligación de iniciar los actos constructivos dentro del plazo de 3 años, según el artículo 120 de la Ley General de Urbanismo y Construcciones contenida en el DFL N ${ }^{\circ}$ 458, de 1976 del Ministerio de Vivienda y Urbanismo, confiere un beneficio e impone una carga material y temporal que condiciona el beneficio.

En este sentido, Bocanegra Sierra señala que la distinción entre actos favorables o declarativos de derechos y actos desfavorables o de gravamen en términos lineales es un error, por cuanto la mayor parte de los actos administrativos no son favorables o desfavorables en un único sentido, sino que por lo general son favorables y restrictivos al mismo tiempo o favorables para algunos y desfavorables para otros.

El mismo autor estima que se debe aplicar el procedimiento de revisión de oficio no solo aquellos actos administrativos que declaran derechos a favor de un particular, sino también respecto de aquellos actos de ventaja que constituyen una restricción respecto de terceros. En suma, se deben someter a un procedimiento todos aquellos actos administrativos de los cuales derive algún perjuicio para alguien, independientemente de que el acto revisado, en sí mismo, pudiera ser considerado como de gravamen o restrictivo ${ }^{56}$.

Una vez aclarado el contenido de los actos administrativos declarativos o constitutivos ante el Derecho Administrativo, a fin de comprender la estructura normativa de esta limitación sustancial, es importante determinar que se debe entender por derechos adquiridos legitimamente materia que, como se verá, es del todo polémica en el Derecho Público y trataremos de abordar tomando en consideración que la revocación transita por la ruta de la eficacia de los actos administrativos.

Hemos afirmado que el legislador ha regulado la potestad revocatoria como un remedio para frenar los efectos perniciosos en el tiempo de un acto administrativo que ha devenido en inoportuno o inconveniente para el interés general, empero dicha potestad no cuestiona ni explora la legalidad o validez del acto administrativo, es más lo presume válido y ejecutorio desde el momento de la notificación o comunicación, de conformidad con los artículos 3 y 45 de la Ley No 19.880, de 2003.

Para estos efectos, dos términos requieren ser precisado a fin de entender la extensión de esta limitación sustancial. En primer lugar, los de-

56 Bocanegra (1977) 256. 
rechos adquiridos es un término de uso frecuente -y a veces abusivo- pero que carece de densidad normativa, explicación dogmática, y sobre todo de comprobación jurisprudencial para entender cuando existe un derecho adquirido digno de amparo ante la potestad de retiro revocatorio. En segundo lugar, y aun existiendo un derecho adquirido, el legislador ha impuesto como requisito adicional que estos sean adquiridos legitimamente, esto es, por medios lícitos y de buena fe.

Los derechos adquiridos en nuestro ordenamiento jurídico, tienen una relación estrecha con el reconocimiento constitucional de derecho de propiedad en sus diversas especies sobre toda clase de bienes corporales o incorporales, y por tanto, con el proceso de propietarización de los derechos de conformidad con el artículo 19 No 24 de la Carta Fundamental. Bajo este contexto, ante de hablar de derechos adquiridos se suele hablar de propiedad sobre cosas incorporales, de situaciones jurídicas consolidadas $^{57}$, de situaciones de ventajas o de efectos favorables.

Para Soto Kloss, un derecho adquirido es aquel que ha ingresado al patrimonio de una persona, y el modo de ingresar al patrimonio va a diferir dependiendo de la naturaleza del derecho, esto es, si se trata de un derecho real o de un derecho personal. Estos últimos requieren de una fuente jurídica generadora de la obligación o derecho. Entre los títulos jurídicos aptos para generar la obligación o derecho, se encuentran la ley ejecutada por el respectivo acto administrativo, el contrato y el cuasidelito en los casos de responsabilidad patrimonial del Estado ${ }^{58}$.

En aquellos casos en que la fuente de los derechos es la ley, bastaría con que el particular beneficiario cumpliese con los requisitos para encontrarse habilitado en la situación de beneficio, y entender que ha adquirido un derecho que ha ingresado a su patrimonio. Para comprobar esta afirmación, podemos observar lo que ocurre en materia de subvenciones escolares, que mediante un acto administrativo de carácter favorable la autoridad pública declara o constituye derechos en el patrimonio del destinatario, para luego efectuar la correspondiente transferencia de recursos desde el patrimonio público hacia el sostenedor educacional. De esta manera, una vez percibidos dichos recursos ellos pierden su carácter de

57 Dictamen N 85976, de 2015, de la Contraloría General de la República. Asimismo, DicTAMEN N $\mathrm{N}^{\circ}$ 96610, de 2015.

58 Soto Kloss (1984) 18. Este planteamiento ha sido recogido por la jurisprudencia de la Corte Suprema, que lleva a sustentar, por ejemplo en materia de funcionarios públicos que la prórroga de las contratas es legítima aunque las municipalidades aún no hayan aprobado el presupuesto para financiarlas. Corte Suprema, 4 de julio de 2013, Rol N².851-2013. 
fondos fiscales ingresando en el patrimonio del sostenedor, adquiriendo la naturaleza de fondos privados ${ }^{59}$.

Adicionalmente, cabe señalar que sobre dichos fondos -asignados legal y reglamentariamente- el Estado pierde la calidad de dueńo y poseedor de dichos fondos, aun cuando estos se encuentren en arcas fiscales en la medida que hayan sido devengados en favor del sostenedor educacio$\mathrm{nal}^{60}$. De este modo, una vez que el sostenedor educacional ha cumplido con todos los requisitos legales y administrativos para obtener la subvención educativa, dicha ayuda pública adquiere el carácter de fondos privados, procediendo sobre ellos integramente el derecho de prenda general. De conformidad con el artículo 15 inciso $2^{\circ}$ del DFL No 2 de 1998, que contiene la Ley de Subvenciones dichos fondos privados pueden ser objeto de embargo u otra medida judicial ${ }^{61}$.

Otro caso relevante se puede plantear en cuanto a la estabilidad de los permisos de edificación, sobre los cuales los derechos adquiridos del titular del permiso se encuentran asegurados incluso antes de la propia emisión del permiso. Ello, porque el legislador le confiere a los permisos de edificación una especie de estabilidad reforzada que se sustentaría en actos administrativos anteriores a su emisión como el certificado de informaciones previas y en el permiso de urbanización. De este modo, el permiso de edificación resulta ser simplemente una consecuencia lógica de la sucesión de actos administrativos que van consolidando la situación jurídica del permisionario.

La jurisprudencia de la Contraloría ha ratificado la afirmación anterior, sosteniendo que los anteproyectos de construcción son fuentes de derechos que los particulares adquieren basados en la legítima confianza que ponen en la Administración del Estado. En esta línea el Dictamen $\mathrm{N}^{\circ}$ 77.490 de 2011 determina que:

"(...) a fin de no dejar en la indefensión al interesado y sobre la base de la confianza otorgada por los derechos que adquirió de buena fe, a partir de la aprobación de su anteproyecto de construcción, adquiere relevancia en este punto, el principio de coordinación establecido en el inciso segundo del artículo $3^{\circ}$ de la ley $N^{\circ} 18.575$ y que desarrollado en el inciso segundo del articulo $5^{\circ}$, de igual cuerpo normativo, dispone que en el cumplimiento

59 Corte Suprema, 2 de septiembre de 1997, Revista de Derecho y Jurisprudencia, t. 94, sec. $3^{\text {a }}$, p. 127. El mismo criterio se repite en los Dictámenes Nos 12.583, de 2007 y 35.236, de 1998.

60 Corte Suprema, 14 de mayo de 2008, Rol N 7055-07. “Consejo de Defensa del Estado con Lucero Gómez, Marcela y otra".

61 Corte Suprema, 14 de abril de 2008, Rol N 6926-07. "Consejo de Defensa del Estado con Catalán Gutiérrez, Jeannette y otra”. 
de sus cometidos los órganos de la Administración del Estado deben actuar coordinadamente y propender a la unidad de acción, evitando la duplicación o interferencia de funciones, lo que, aplicado a la actividad unilateral de la Administración, impone el respeto a los actos que cada uno de ellos ha emitido dentro de su respectiva esfera de atribuciones".

Como se puede apreciar los anteproyectos de construcción generan derechos adquiridos de buena fe que impediría a los órganos administrativos sectoriales ejercer la potestad revocatoria por encontrarse expresamente limitados por el artículo 61 de la Ley $\mathrm{N}^{\circ} 19.880$, de 2003, que se extiende no solo a las situaciones jurídicas consolidadas en forma evidente, sino que también a las consecuencias jurídicas constituidas o declaradas al amparo de ellas ${ }^{62}$.

Por su parte, el término legitimamente se debe entender como sinónimo de un comportamiento amparado en la buena fe, libre de fraudes o deslealtades hacia los órganos públicos, que les impide a estos volver sobre las situaciones beneficiosas invocando razones de interés público. De este modo, la obtención de una situación de ventaja derivada de un acto administrativo regular, debe quedar comprendida dentro del marco de la buena fe, de la confianza de la Administración en la licitud de los medios propuestos por el particular para acceder a los actos beneficiosos del Estado.

A nuestro parecer la exigencia de legitimidad en la adquisición de los derechos contenidos en actos declarativos o constitutivos, se relaciona con las posibles actitudes fraudulentas en que podrían incurrir los particulares para obtener situaciones de beneficios, como proporcionar documentación falsa o adulterada, omitir información específica para obtener un beneficio estatal, v.gr., certificados falsos para ser acreedor de una beca o mentir en el grado de experiencia previa para ser concesionario en un área determinada.

En este sentido se puede considerar que el actuar legítimo para la adquisición de derechos derivados de actos declarativos o constitutivos no comprende situaciones de ilegalidades manifiestas de los actos administrativos para invocar su extinción por la vía de la potestad revocatoria, atendido que ante ilegalidades manifiestas la Administración se vería tentada a extinguir el acto administrativo a través de la potestad invalidatoria, que si bien ofrece una mayor garantía procedimental, por la presencia de una audiencia previa y un plazo expreso de caducidad para su ejercicio carece de las limitaciones sustanciales que ofrece el instituto revocatorio. 
Precisamente la mala fe del beneficiario impediría la adquisición del beneficio estatal, y por ende, no podría invocarse la titularidad del beneficio como una excepción a la potestad revocatoria. Estimamos, que la autoridad administrativa podría optar entre ejercer la potestad revocatoria ilimitada -sin mayores controles adjetivos- o acudir a la potestad invalidatoria, dando cumplimiento a las exigencias procedimentales del artículo 53 de la Ley $\mathrm{N}^{\circ} 19.880$.

\section{(4.2.) La SitUaCión ESPECIAL DE LOS ACTOS ADMINISTRATIVOS DE GRAVAMEN}

El legislador omitió toda referencia a la procedencia de la potestad revocatoria respecto de los actos administrativos que imponen un gravamen o que resultan desfavorables para los particulares. Por tanto, en principio los actos administrativos que imponen gravámenes, cargas o multas no constituirían limitaciones a la potestad revocatoria, pudiendo los órganos administrativos por razones de oportunidad, mérito o conveniencia disponer de los efectos de un acto de gravamen discrecionalmente.

Hemos adelantado que los actos administrativos de gravamen son aquellos que restringen el patrimonio de las personas al imponer una prohibición, multa o clausura que le impide el normal ejercicio de sus derechos. En sentido, una interpretación contrario sensu del artículo 61 de la Ley $\mathrm{N}^{\circ} 19.880$, de 2003 potencialmente permitiría que se pudiese invocar ilimitadamente la revocación de los actos administrativos de gravamen. Este planteamiento que en su elaboración parece simple, porque tiene por objeto corregir el desajuste entre el interés general y el objetivo específico en un acto de gravamen, debe someterse a ciertas exigencias que impidan un acto de benevolencia injustificada a favor de quienes sufren un gravamen en perjuicio de terceros.

Estimamos, que una exigencia que debe ser superada para propiciar una eventual revocación de un acto de gravamen, consiste en la extensión de la interpretación que se le puede atribuir al artículo 61 de la Ley $\mathrm{N}^{\circ}$ 19.880. Concretamente, si se podría sostener fundadamente que una interpretación a contrario sensu de este precepto es antecedente suficiente para el reconocimiento general sobre la potestad revocatoria de los actos de gravamen aplicables a todos los órganos de la Administración del Estado, o es necesario que la propia ley sectorial ratifique dicha interpretación atribuyendo específicamente a los órganos públicos la potestad revocatoria sobre los actos de gravamen.

Para resolver esta interrogante es preciso volver sobre las exigencias del principio de juridicidad para la atribución de potestades en el 
Derecho Administrativo, que consagrado en el artículo 7 de la Carta Fundamental dispone que las potestades deben ser expresamente atribuidas, sin que se pueda plantear la existencia de potestades implícitas o presuntas. Bajo este entendido, no sería suficiente para sostener la presencia de la potestad revocatoria respecto de los actos de gravamen la mera interpretación garantista del artículo 61 de la Ley $\mathrm{N}^{\circ} 19.880$, máxime cuando la autoridad administrativa ejerciendo esa potestad podría perjudicar los derechos o intereses de tercero, e infringir la regla constitucional de la igualdad y proscripción de discriminaciones arbitrarias.

Siguiendo esta interpretación, cada vez que la Administración pretendiese invocar la potestad revocatoria de un acto de gravamen es preciso que el ejercicio de esa potestad se ampare en un fundamento más sólido que la mera interpretación a contrario sensu del artículo 61, ello por las fuertes exigencias del principio de legalidad en materia de actos de gravámenes, máxime frente a actos administrativos de carácter sancionador. Refuerza este planteamiento, la letra b) del mismo precepto que restringe la revocación en aquellos casos donde el legislador ha regulado una forma distinta de extinción del acto administrativo.

Al respecto, la Contraloría General de la República conociendo sobre la procedencia de invocar la potestad revocatoria para dejar sin efecto multas aplicadas por la Dirección de Trabajo, dictaminó que:

“(...) en su artículo 511, establece la facultad del Director del Trabajo, en las condiciones que se disponen, de reconsiderar las multas impuestas por personal de su dependencia, dejándolas sin efecto cuando aparezca de manifiesto que se ha incurrido en un error de hecho al aplicarla $-N^{\circ} 1-o$ rebajándolas, si se acredita fehacientemente haber dado integro cumplimiento a las disposiciones cuya infracción motivó la sanción $-N^{\circ} 2$. El Código del Trabajo ha regulado en forma expresa otras formas de extinción de tales actos administrativos, procede señalar que a su respecto concurre el anotado supuesto establecido en el artículo 61, inciso segundo, letra b), de la ley $N^{\circ} 19.880$, por lo que resulta improcedente disponer su revocación"63.

En este sentido, la Contraloría también ha prohibido la creación de revocaciones por vía de normas infralegales, afirmando que resulta improcedente que las municipalidades por intermedio de una ordenanza local establezcan clausuras, revocaciones o caducidades de patentes ante ciertas conductas no previstas legalmente, pues carecen de facultades para ello ${ }^{64}$.

63 Dictamen N $\mathrm{N}^{\circ} 59.466$, de 2015.

64 Dictamen N $\mathrm{N}^{\circ} 54.966$, de 2013. 
Por último, estimamos que si bien puede parecer atractivo jurídicamente el ejercicio de la potestad revocatoria sobre un acto administrativo de gravamen, es preciso ser cautelosos de no abrir una puerta para la introducción de desigualdades, que motiven a la Administración del Estado a ejercer abusivamente la potestad revocatoria para favorecer solo a ciertos sectores, máxime cuando el artículo 61 ofrece mínimas garantías procedimentales de debido proceso. De esta forma, no basta la mera motivación del acto administrativo revocatorio para dejar sin efecto un acto de gravamen, sino que es preciso dar la oportunidad a los interesados de exponer sus argumentos sobre la permanencia del acto sancionador, v.gr., resulta relevante para terceros exponer fundadamente su oposición a un acto revocatorio de una clausura sanitaria del Seremi de Salud.

\section{(4.3.) IMPROCEDENCIA DE LA REVOCACIÓN DE ACTOS ADMINISTRATIVOS REGLADOS}

Por último, la potestad revocatoria también encuentra una nítida limitación en aquellos actos administrativos cuyos efectos no se prolongan en el tiempo sobre los cuales la autoridad administrativa no tiene disponibilidad sobre sus efectos jurídicos.

De este modo, no serían revocables los actos administrativos reglados, cuyos efectos están perfectamente regulados desde el instante mismo que el acto nace a la vida jurídica, y no podría por norma general la Administración resolver que estos efectos dejen de existir, sobre todo cuando la ley es la que determina los procedimientos para modificar ese acto, para cambiarlo por otro, o para hacerlo desaparecer.

En este sentido, ha señalado la Contraloría General de la República que:

"La revocación está limitada en los actos administrativos cuyos efectos están reglados por ley, como son los que otorgan jubilaciones, los que, perfeccionados, no pueden invalidarse discrecionalmente por la autoridad (...) concedida la jubilación, esta es irrenunciable e imprescriptible, como derecho definitivo, no puede dejarse sin efecto, a menos que se incurriera en error de hecho o derecho, pues en ese caso, la administración está facultada y tiene el imperativo de rectificarla o invalidarla' ${ }^{35}$.

Por su parte, la Corte Suprema -asumiendo la naturaleza de acto administrativo de constancia de los Certificados de Recepciones Municipales- ha sentenciado que: 
"(...) no existiendo en el otorgamiento de la recepción definitiva un vicio de legalidad y siendo un acto de contenido favorable al particular, no ha podido ser revocado ni invalidado por la autoridad, por lo que al hacerlo se ha afectado la garantía del derecho de propiedad contemplado en el artículo $19 N^{o} 24$ de la Constitución Politica que se tiene, no sobre el certificado de recepción definitiva, sino que sobre el ejercicio del derecho de dominio sobre el inmueble en que el permiso recae y que este ha habilitado" 66.

De este modo, cuando los efectos del acto se encuentre reglamentados en forma específica, la Administración se encuentra impedida de ejercer la potestad revocatoria, por cuanto existirían otras causales de extinción del acto administrativo o el legislador ha regulado causales distintas de extinción de los efectos del acto, de conformidad con las letras b) y c) del artículo 61 de la Ley $N^{\circ} 19.880$, de 2003.

\section{ConClusiones}

Una vez analizados los elementos más relevantes de las potestades de retiro de la Administración del Estado, específicamente la potestad revocatoria, podemos esbozar las siguientes conclusiones:

1) La potestad revocatoria del artículo 61 es perfectamente distinguible en su objeto, motivos, sujetos, procedimiento, efectos y limitaciones de la potestad invalidatoria regulada en el artículo 53 de la Ley $\mathrm{N}^{\circ}$ 19.880 , de 2003, sobre procedimiento administrativo.

2) El legislador ha omitido una regulación íntegra de la potestad revocatoria, por tanto se debe acudir a la doctrina y la jurisprudencia para configurar un concepto unívoco de la revocación. De este modo, se entiende por revocación la extinción de un acto administrativo, y consecuencialmente, de sus efectos por el desajustes con el interés general en un momento determinado, por razones de mérito, conveniencia u oportunidad.

3) Tampoco el artículo 61 de la Ley $\mathrm{N}^{\circ}$ 19.880, de 2003, entrega al intérprete jurídico la distinción de los elementos típicos de la potestad revocatoria. Ello obliga nuevamente a acudir a la doctrina y la jurisprudencia para detectar, que el sujeto activo de la potestad revocatoria es la misma autoridad que dictó el acto administrativo; que su objeto es extinguir los efectos del acto administrativo válido, pero inconveniente e inoportuno con el interés general sobreviniente; que el motivo es precisamente el cambio de apreciación en el interés ge- 
neral que contraviene el objeto mismo del acto administrativo cuya revocación se pretende; y que los efectos del ejercicio de la potestad revocatoria debe respetar las situaciones jurídicas anteriores a la emisión del acto administrativo revocatorio, por cuanto la validez del acto revocado hace que la revocación solo opere hacia el futuro.

4) De conformidad con el artículo 61 de la Ley $\mathrm{N}^{\circ} 19.880$, de 2003, la potestad revocatoria reconoce límites sustanciales en los actos administrativos declarativos o constitutivos de derechos adquiridos legítimamente, entregando tácitamente la integración de estos conceptos a la labor de la doctrina y la jurisprudencia. De este modo, los derechos adquiridos son aquellos provenientes de actos administrativos favorables, que han ingresado en el patrimonio del destinatario de buena fe.

\section{Bibliografía}

Aguerrea, Pedro (2003) "Las prerrogativas del acto administrativo en la Ley $\mathrm{N}^{\circ} 19.880$ ". AAVV., Ley $N^{\circ} 19.880$ sobre procedimientos administrativos, conferencias Santo Tomás de Aquino, pp. 45-50.

Almeida Cerrera, Marcos (2010) "El principio de irrevocabilidad de los actos favorables". En Santamaría Pastor, Juan Alfonso (Director): Los principios jurídicos del Derecho Administrativo. Madrid: La Ley, pp. 1103-1135.

Aróstica, Iván (1984) "La extinción de los actos administrativos y la jurisprudencia reciente de los tribunales de justicia". Revista Chilena de Derecho, No 11, pp. 433-448.

Aróstica, Iván (2013) "La actividad jurídica de la Administración del Estado". Revista de Actualidad Jurídica, Universidad del Desarrollo. No 28, pp. 261-290.

Baca Oneto, Víctor (2006) La invalidez de los contratos públicos. Pamplona: Civitas, 442 pp.

Bandeira de Mello, Celso (2006) Curso de Derecho Administrativo, Porrúa, México D.F., 630 pp.

Bermúdez, Jorge (2011) Derecho Administrativo General. 2a edición. Santiago: Thomson Reuters, $603 \mathrm{pp}$.

Bermúdez Soto, Jorge (2005) "El principio de confianza legítima en la actuación de la Administración como límite a la potestad invalidatoria". Revista de Derecho de la Universidad Austral de Chile, XVIII No 2, pp. 83-105.

BocANEGRA, Raúl (1977) La revisión de oficio de los actos administrativos. Madrid: Instituto de Estudios de la Administración Local, 303 pp. 
Bocanegra, Raúl, Lecciones sobre el acto administrativo, Civitas, 2a edic., Madrid, 2004, 256 pp.

Bocanegra, Raúl (2005) Teoría del acto administrativo. Madrid: Iustel, 216 pp.

Boquera Oliver, José María (1977) La irrevocabilidad de los actos administrativos, Moneda y Crédito, Madrid, 187 pp.

Caldera Delgado, Hugo (2001) Tratado de Derecho Administrativo, Ediciones Parlamento, Santiago, t. II, 705 pp.

Cassagne, Juan Carlos (1974) El acto administrativo, AbeledoPerrot, 2a edic., Buenos Aires, 450 pp.

Cordero, Luis (2015) Lecciones de Derecho Administrativo. Santiago: Thomson Reuters, 786 pp.

Díez, Manuel María (1956) El acto administrativo, Tipográfica Editora Argentina, Buenos Aires, 560 pp.

Fernández de Velasco, Recaredo (1929). El acto administrativo. Madrid: Librería General de Victoriano Suárez, 333 pp.

Ferrada, Juan Carlos (2007). "La potestad invalidatoria de los órganos de la Administración del Estado" "AA.VV"., Acto y Procedimiento Administrativo. Actas de las Segundas Jornadas de Derecho Administrativo. Valparaíso: Edeval, pp. 131-147.

Fortes Martín, Antonio (2006). "Estudio sobre la revocación de los actos administrativos". Revista de Derecho de la Universidad Austral de Chile, XIX, No 1, pp. 149-177.

García de Enterría, Eduardo y Fernández, Tomás-Ramón (2011) Curso de Derecho Administrativo, 15a edición. Pamplona: Thomson Reuters, t. I, 872 pp.

García-Trevijano, José Antonio (1986) Los actos administrativos. Madrid: Civitas, 438 pp.

Huepe Artigas, Fabián (2013) "El principio de irretroactividad de los actos administrativos como límite a la potestad invalidatoria de la Administración”. En Bocksang Hola, Gabriel y Lara Arroyo, José Luis (Coordinadores): Procedimiento administrativo y contratación pública. Santiago: LegalPublishing, pp. 147-177.

Iribarren, Juan Antonio (1936) Lecciones de Derecho Administrativo. Santiago: Nascimento, 203 pp.

Jara, Jaime (2004) La nulidad de derecho público ante la doctrina y la jurisprudencia. Santiago: Libromar, 285 pp.

Laguna de Paz, José Carlos (2006) La Autorización Administrativa. Navarra: Thomson Civitas, 378 pp.

Letelier Wartenberg, Raúl (2014) “Contra la confianza legítima como límite a la invalidación de actos administrativos". Revista Chilena de Derecho, Volumen 41, N², pp. 609-634 
Marienhoff, Miguel (1993) Tratado de Derecho Administrativo. 4a edición. Buenos Aires: Abeledo-Perrot, t. II, 850 pp.

Marín Vallejo, Urbano (2000) "Vigencia actual de la invalidación de los actos administrativos". Revista de Derecho del Consejo de Defensa del Estado, No 1, pp. 45-60.

Millar Silva, Javier (2003) "La potestad invalidatoria en la jurisprudencia nacional. Procedencia, alcance y limitaciones". Revista de Derecho, Universidad Austral de Chile, XIV, pp. 83-98.

Millar Silva, Javier (2000) La potestad invalidatoria en el Derecho chileno. Tesis Doctoral [inédita], Universidad de Chile, 315 pp.

Moraga Klenner, Claudio (2010) "La Actividad formal de la Administración del Estado”. En Pantoja Bauzá, Rolando, (Coordinador): Tratado de Derecho Administrativo, Santiago: LegalPublishing, t. VII, 574 pp.

Morón Urbina, Juan Carlos (2011) "La revocación de actos administrativos, interés público y seguridad jurídica”. Revista Derecho PUCP, No 67, pp. 419-455.

Olguín, Hugo (1961) Extinción de los actos administrativos. Revocación, invalidación y decaimiento. Santiago: Editorial Jurídica de Chile, 293 pp.

Salas Arquer, José Manuel (1974). La revocación de los actos administrativos en el Derecho Español. Madrid: Instituto de Estudios Administrativos, 300 pp.

Silva Cimma, Enrique (1995) Derecho Administrativo Chileno y Comparado. Actos, contratos y bienes., Santiago: Editorial Jurídica de Chile, 336 pp.

Soto Kloss, Eduardo (1984) "Los derechos adquiridos en el Derecho Público Chileno. (Réquiem para una inepcia doctrinaria)". Revista de Derecho y Jurisprudencia, 81, Derecho, pp. 13-23.

Sото KLoss, Eduardo (2014) "Inestabilidad del acto administrativo y derecho de los destinatarios (A propósito del artículo 53 inciso $1^{\circ}$ de la Ley $\mathrm{N}^{\circ}$ 19.880)". En Soto Kloss, Eduardo (Coordinador): Administración y Derecho. Santiago: Thomson Reuters, pp. 283-297

Sото Kloss, Eduardo (1996) Derecho Administrativo. Bases fundamentales. Santiago: Editorial Jurídica de Chile, t. II, 480 pp.

Sото Kloss, Eduardo (1989) "Invalidación de los actos administrativos". Revista Chilena de Derecho, Volumen 16, N² 2, pp. 476-480,

VARGas Zincke, Osvaldo (1995) "Algunos aspectos sobre la invalidación en la jurisprudencia de la Contraloría General de la República". Gaceta Jurídica, № 178, pp. 35-41. 


\section{JURISPRUDENCIA}

Corte Suprema, 2 de septiembre de 1997, Revista de Derecho y Jurisprudencia, t. 94 , sec. $3^{\text {a }}$.

Corte Suprema, 14 de mayo de 2008, Rol No 7055-07. "Consejo de Defensa del Estado con Lucero Gómez, Marcela y otra".

Corte Suprema, 14 de abril de 2008, Rol No 6926-07. "Consejo de Defensa del Estado con Catalán Gutiérrez, Jeannette y otra”.

Corte Suprema, 26 de octubre de 2009, Rol No 2246-2009.

Corte Suprema, 21 de septiembre de 2009, Rol No6014-09.

Corte Suprema, 18 de octubre de 2011, Rol N²437-2011.

Corte Suprema, 27 de octubre de 2005, Rol No 5.202-05.

Corte Suprema, 23 de junio de 2011, Rol No 6379-2011.

Corte Suprema, 18 de mayo de 2009, Rol No 2.614-2009.

Corte Suprema, 23 de junio de 2011, Rol No 6379-2009.

Corte Suprema, 4 de julio de 2013, Rol No 2.851-2013.

Corte Suprema, 29 de octubre de 2007, Rol No 4.800-2007.

Dictamen No 35.081, de 2014.

Dictamen No 85976, de 2015.

Dictamen N ${ }^{\circ}$ 96610, de 2015.

Dictamen N ${ }^{\circ} 12.583$, de 2007

Dictamen N 35.236, de 1998.

Dictamen No 77.490 de 2011.

Dictamen N ${ }^{\circ} 59.466$, de 2015.

Dictamen N $N^{\circ} 54.966$, de 2013.

Dictamen N 4614, de 2004. 